\title{
An Examination of High School Social Science Students' Levels Motivation towards Learning Geography
}

\author{
Tahsin Yildırım ${ }^{1}$ \\ ${ }^{1}$ Faculty of Education, Aksaray University, Turkey \\ Correspondence: Tahsin Yıldırım, Faculty of Education, Aksaray University, Aksaray, Turkey. E-mail: \\ yildirimtahsin33@gmail.com
}

Received: January 26, 2017

Accepted: March 10, $2017 \quad$ Online Published: June 27, 2017

doi:10.5539/ies.v10n7p1

URL: https://doi.org/10.5539/ies.v10n7p1

\begin{abstract}
This aim of this research was to examine the levels of motivation among high school social science students towards learning geography. The study group consisted of 397 students from different classes at Aksaray Ahmet Cevdet Paşa High School in the College of Social Science. The research was carried out with a scanning model, with data obtained using the Scale for Motivation Towards Learning Geography. In the analysis of the data, the t-test and the one-way analysis of variance (ANOVA) were used. As a result of the research, the levels of motivation among social science students towards learning geography were found to be moderate. From the analysis of the aforementioned scale's subfactors, those related to the interest of students and information acquisition were found to be 'undecided', while the subfactors related to self-confidence and performance were found to be 'in agreement'. It was determined that the level of motivation towards learning geography reported in the findings, with regard to the gender variable, showed a significant difference among male students. In addition, it was indicated that the motivation levels of male students were higher for the subfactors of interest and self-confidence than those of female students. In terms of the subfactors of information acquisition and performance, no significant changes were found in the motivation levels among both male and female students. Analyses based on class level demonstrated that the average scores of the students differ in this context, but that this difference was found to be statistically significant for 11th grade students for the subfactor of self-confidence.
\end{abstract}

Keywords: motivation, geography, geography education, motivation towards learning geography, high school students in social science

\section{Introduction}

Education, which is a multidimensional process, continues throughout life. While guiding and directing our learning activities in educational institutions are expressed as teaching, permanent behavior change is expressed as learning, which represents the last stage of teaching (Demirel, 2009). It can be said that students do not have similar attitudes to every subject they are taught in the learning environment. It has been noted that some students who do not care about their lessons prefer to escape from the learning environment rather than produce solutions to the problems they encounter. One of the most important reasons behind the emergence of this difference among students is motivation. The concept of motivation or the act of motivation can be defined in terms of a person's direction towards certain behaviors and what prompts a person to continue these behaviors (Akbaba, 2006). Put another way, motivation is the power that provides guidance and energy in order to achieve a specific goal. Motivation represents an extremely important function in the emergence of behavior and learning (Yüksel, 2011).

Learning motivation is connected to a goal to be achieved, which shows itself as the result of effort and persistence, as well as initiates and sustains students' learning activities (Hu, 2008). In other words, it can be defined as a process in which the student can establish a psychological connection with other learners, participate in the learning process and develop their behavior; it can also lead to a continuous learning activity (Kaya, 2013). It is stated that learning cannot be processed without motivation, such that an unmotivated student cannot be successful. The continuity of motivation is an important factor when starting a process of learning (Girmus, 2011).

In some cases, teaching may involve students who are not motivated to learn, even if they apply a lot of effort 
(Yüksel, 2011). Motivation towards learning involves two dimensions: internal and external motivation. The desire to be competent, interested, productive and focused on results is effective in the emergence of internal motivation. It is internal motivation that is more effective when learning. Those students who are internally motivated think that learning is about studying, which leads to success at the end of a great deal of hard work, such that it is not a waste of effort. For example, a student who is interested in geography will try to learn about this subject by focusing their own initiative and industry, without any constraint, on the acquisition of new knowledge, with internal motivation representing the desire to be successful. External motivation comes from external influences, such as reward, expectation of appreciation, punishment, oppression and praise. An example of external motivation is when students work hard during geography lessons in order to obtain higher grades or to be appreciated (Gülşen, 2015; Ergün, 2014; Yüksel, 2011).

In particular, teachers' behaviors and teaching methods applied in the classroom environment and throughout the course in question positively or negatively affect students' motivation, although factors affecting motivation in learning environments do vary (Frymier, 1993). When the relationship between motivation and learning is examined, it can be said that teachers have an important role to motivate the students towards learning (Loima \& Vibulphol, 2016). During lessons, teachers need to make every topic interesting to their students, if the desire to learn throughout life is to be nurtured, by introducing practical exercises and using different techniques. Meanwhile, students need to understand what they are learning and learn how to apply knowledge in order to reach their goals and encourage them to develop self-confidence (Özbay, 2003). It has been reported that the interest among students to learn has a big effect on motivation and influences their desire to learn and complete their courses of study in a positive way (Ainley, 2006). It is also necessary for students to experience motivational teaching practices in accordance with their cognitive levels in the classroom, while increasing their pursuit of achievement (Kubanyiova, 2006). It is asserted that any course will contribute to the success and learning desire of students if it considers their preferred learning styles in the course planning stages (Sezer, 2006). It is critical for teachers to give importance to their teaching model and encouragement of their students. From this point of view, teachers can help their students develop positive motivational beliefs by organizing the teaching schedule with their cognitive levels, current expectations, future goals and skills. It is stated that both short- and long-term achievements have emerged due to these positive learning approaches in the classroom environment (Mensah, 2015).

The research conducted in different areas reveal that motivation and motivational activities have positive effects on learning (Batdı \& Semerci, 2016; Noland \& Richards, 2014; Göğüş \& Yetke, 2014; Singh, Kleeman, \& Van-Bergen, 2013; Moos \& Honkomp, 2011; Aydın, 2009; Dörnyei, 2000). When the importance of motivation towards learning is taken into consideration, with a view to achieving success in the teaching of geography, it is necessary to determine the levels of motivation among students towards learning this subject and to act in this regard.

It is inevitable that, when students lose their interest in geography courses, the subject will be difficult to understand and become boring for them. Put another way, it cannot be said that a student who is insufficiently motivated enough is ready to learn, nor can they be expected to be successful. In order to overcome these problems, it is necessary for the student to be active in the learning process and be motivated to participate in the class (Aydin, 2010b).

The fact that students are motivated to learn is very important if geography teaching is to be effective. When the literature was examined, no study could be found on the motivation levels of high school social science students towards learning geography. Therefore, it is thought that the results obtained from this study will help to increase such students' motivation levels when learning about geography, organize teaching programs and classrooms, and contribute to the teaching of geography courses.

The aim of this study is to examine the motivation levels of social science students when learning about geography from different perspectives. In the process, the following questions are addressed:

1) What is the level of motivation among students when learning about geography?

2) What is the level of motivation among students in terms of interest, self-confidence, information acquisition and performance?

3) Is there a meaningful difference between students' gender and their motivation to learn about geography?

4) Is there a meaningful difference between students' class levels and their motivation to learn about geography? 


\section{Method}

\subsection{Research Model}

This research is conducted as a scanning model. This kind of model aims to depict its own function without any intervention in the past or in the current situation (Karasar, 2011).

\subsection{Study Group}

After the necessary permissions were obtained, the study was carried out at Aksaray Ahmet Cevdet Paşa High School. The study group consisted of 397 students from the social science department, which is different from other departments because geography lessons involve more hours of teaching and are compulsory for all students. It is the case that the majority of the students not only has a preference for social sciences, but can also expect to be placed in social science-oriented programs after their graduation from university. This situation determines the level of motivation among students towards learning geography. Table 1 shows the distribution of the study group according to gender and class level.

Table 1. The distribution of the study group according to gender and class level

\begin{tabular}{lcccc}
\hline & \multicolumn{2}{c}{ Gender } & \multicolumn{2}{c}{ Class level } \\
\hline & $f$ & $\%$ & $f$ & $\%$ \\
\cline { 2 - 5 } Female & 250 & 62.97 & & \\
Male & 147 & 37.03 & & \\
Class 9 & & & 120 & 30.23 \\
Class 10 & & & 114 & 28.71 \\
Class 11 & & & 101 & 25.44 \\
Class 12 & & & 62 & 15.62 \\
Total & 397 & 100 & 397 & 100 \\
\hline
\end{tabular}

\subsection{Data Collection Tool}

The research data were collected with the use of the Scale for Motivation Towards Learning Geography. The elements of the scale, which involves a type of five-point Likert scale with 22 items, are divided into four subfactors, developed by Kaya (2013), as follows:

- First factor (F1): 1-2-3-4-5-6 for interest

- Second factor (F2): 7-8-9-10-11 for self-confidence

- Third factor (F3): 12-13-14-15-16-17-18 for information acquisition

- Fourth factor (F4): 19-20-21-22 for performance

The Cronbach's alpha value of the scale was found to be: $.812, .811, .818$ and .710 , respectively. As a result of the reliability and validity analysis for this research, the Cronbach's alpha value of the scale is calculated as: $.837, .910, .818$ and .900 , respectively. The lowest score that can be taken from the scale is 22 and the highest score is 110 . Table 2 demonstrates the scores for the subscales of the scale.

Table 2. The scores for the subfactors of the Scale for Motivation Towards Learning Geography (Kaya, 2013)

\begin{tabular}{lcccccc}
\hline Factor & Numbers of items & I do not totally agree & I do not agree & I am indecisive & I agree & I totally agree \\
\hline Factor 1 & 6 & $6-10.8$ & $10.9-15.6$ & $15.7-20.4$ & $20.5-25.2$ & $25.3-30$ \\
Factor 2 & 5 & $5-9$ & $9.1-13$ & $13.1-17$ & $17.1-21$ & $21.1-25$ \\
Factor3 & 7 & $7-12.6$ & $12.7-18.2$ & $18.3-23.8$ & $23.9-29.4$ & $29.5-35$ \\
Factor 4 & 4 & $4-7.2$ & $7.3-10.4$ & $10.5-13.6$ & $13.7-16.8$ & $16.9-20$ \\
\hline
\end{tabular}

\subsection{Analysis of Data}

In the analysis of the data, the t-test and one-way ANOVA were used for unbound groups. The research data were interpreted by taking into account the arithmetic average, percentage, frequency and level of significance. The level of significance in the evaluation of statistics (p .05) was acceptable. 


\section{Findings and Interpretation}

The analysis of the results and interpretations of the obtained data in line with the aim of this study are given in this section.

Table 3. The descriptive statistics of the scores for learning geography: scale and subfactors

\begin{tabular}{lccccc}
\hline Scale/subfactors & $\mathrm{N}$ & Min. score & Max. score & $\bar{X}$ & Ss \\
\hline Total & 397 & 22 & 106 & 70.47 & 15.38 \\
F1: interest & 397 & 6 & 30 & 17.23 & 5.03 \\
F2: confidence & 397 & 5 & 25 & 17.18 & 4.74 \\
F3: information acquisition & 397 & 7 & 35 & 20.33 & 5.60 \\
F4: performance & 397 & 4 & 20 & 15.72 & 4.32 \\
\hline
\end{tabular}

When Table 3 is examined, it can be seen that the average score from the motivation scale for high school students in social sciences who are learning geography is $\bar{X}=70.47$. It can be said that the motivation among students towards learning geography is moderate when considering that the lowest score from the scale is 22 and the highest score is 110 . As a result of the analysis, according to the scale's subfactors of the scale, it can be seen that the average scores of the students are approximately as follows: F1: $\bar{X}=17.23, \mathrm{~F} 2: \bar{X}=17.18, \mathrm{~F} 3: \bar{X}=20.33$ and F4: $\bar{X}=15.72$ According to Table 2, which shows the scores and the scale's subscales, the factors of information acquisition and interest are stated as 'indecisive', while the factors of confidence and performance are confirmed by 'I agree' responses from the high school social science students. These results demonstrate that the level of motivation in terms of self-confidence and performance is higher than for other subfactors among these students.

Table 4. The results of the analysis based on the Scale for Motivation Towards Learning Geography according to gender

\begin{tabular}{cccccc}
\hline Gender & $\mathrm{N}$ & $\bar{X}$ & $\mathrm{Ss}$ & $\mathrm{t}$ & $\mathrm{p}$ \\
\hline Female & 250 & 69.12 & 14.32 & 2.287 & $.023^{*}$ \\
Male & 147 & 72.76 & 16.84 & & \\
\hline$* \mathrm{p}<.05$ & & & & &
\end{tabular}

When Table 4 is examined, it can be seen that the average score for the level of motivation among girls in respect of learning geography is $\bar{X}=69.12$, while for male students it is $\bar{X}=72.76$. The level of motivation among students towards learning geography is different between gender $(\mathrm{t}=2.287 ; \mathrm{p}<.05)$. Accordingly, it can be said that male students' level of motivation towards learning geography is statistically higher than for female students.

Table 5. The results of analysis based on the motivation subfactors in respect of learning geography according to gender

\begin{tabular}{|c|c|c|c|c|c|c|}
\hline Subfactors & Gender & $\mathrm{N}$ & $\bar{X}$ & Ss & $\mathrm{t}$ & $\mathrm{p}$ \\
\hline \multirow{2}{*}{ F1: interests } & Girl & 250 & 16.60 & 4.66 & \multirow{2}{*}{3.313} & \multirow{2}{*}{$.001 *$} \\
\hline & Boy & 147 & 18.31 & 5.46 & & \\
\hline \multirow{2}{*}{ F2: confidence } & Girl & 250 & 16.60 & 4.36 & \multirow{2}{*}{3.196} & \multirow{2}{*}{$.002 *$} \\
\hline & Boy & 147 & 18.16 & 5.20 & & \\
\hline \multirow{2}{*}{ F3: information acquisition } & Girl & 250 & 20.02 & 5.40 & \multirow{2}{*}{1.402} & \multirow{2}{*}{.162} \\
\hline & Boy & 147 & 20.84 & 5.91 & & \\
\hline \multirow{2}{*}{ F4: performance } & Girl & 250 & 15.89 & 4.07 & \multirow{2}{*}{1.001} & \multirow{2}{*}{.318} \\
\hline & Boy & 147 & 15.44 & 4.71 & & \\
\hline
\end{tabular}

$* \mathrm{p}<.05$

According to Table 5, the subfactors of the subscale for $\mathrm{F} 1(\mathrm{t}=3.313 ; \mathrm{p}<.05)$ and $\mathrm{F} 2(\mathrm{t}=3.196 ; \mathrm{p}<.05)$ involve 
statistically significant differences between male and female students. For the subfactors for $F 3(t=1.402 ; p>.05)$ and F4 ( $\mathrm{t}=1.001 ; \mathrm{p}>.05)$, there is no statically important difference between male and female students.

This finding can be interpreted in a way that the level of motivation in respect of male students' interests and self-confidence is higher than that for female students, while the level of motivation in respect of information acquisition and performance involves no meaningful difference based on gender.

Table 6. The results of analysis for the motivation scale and subfactor scores according to the class level for learning geography

\begin{tabular}{llccc}
\hline Scale/subfactors Class & & N & $\bar{X}$ & Ss \\
\hline \multirow{3}{*}{ Total } & Class 9 & 120 & 68.22 & 15.17 \\
& Class 10 & 114 & 69.80 & 13.68 \\
& Class 11 & 101 & 73.53 & 15.28 \\
& Class 12 & 62 & 71.04 & 18.21 \\
& Class 9 & 120 & 16.49 & 5.16 \\
F1: interest & Class 10 & 114 & 17.06 & 4.65 \\
& Class 11 & 101 & 18.20 & 5.11 \\
& Class 12 & 62 & 17.40 & 5.19 \\
F2: confidence & Class 9 & 120 & 16.18 & 4.93 \\
& Class 10 & 114 & 16.49 & 4.46 \\
& Class 11 & 101 & 18.78 & 3.78 \\
F3: information acquisition & Class 12 & 62 & 17.77 & 5.56 \\
& Class 9 & 120 & 19.65 & 5.58 \\
& Class 10 & 114 & 19.97 & 4.99 \\
& Class 11 & 101 & 21.33 & 5.55 \\
F4: performance & Class 12 & 62 & 20.66 & 6.56 \\
& Class 9 & 120 & 15.90 & 4.39 \\
& Class 10 & 114 & 16.28 & 3.87 \\
& Class 11 & 101 & 15.20 & 4.35 \\
& Class 12 & 62 & 15.20 & 4.83 \\
\hline
\end{tabular}

In Table 6, it can be seen that the average scores of the motivation scale and subfactors among the high school social science students differ according to class level. The results of the ANOVA, as based on the significance levels of this difference, are presented in Table 7.

Table 7. The results of the ANOVA of the motivation scale and subfactor scores according to class level in respect of learning geography

\begin{tabular}{|c|c|c|c|c|c|c|c|}
\hline Scale/subfactors & Source of assumption & Sum of squares & SD & Mean square & $\mathrm{F}$ & $\mathrm{p}$ & Significant difference \\
\hline \multirow{3}{*}{ Total } & Between groups & 1624.254 & 3 & 541.418 & & & \\
\hline & Within groups & 92146.663 & 393 & 234.470 & 2.309 & .076 & - \\
\hline & Total & 93770.917 & 396 & & & & \\
\hline \multirow{3}{*}{ F1: interest } & Between groups & 167.099 & 3 & 55.700 & & & \\
\hline & Within groups & 9880.115 & 393 & 25.140 & 2.216 & .086 & - \\
\hline & Total & 10047.214 & 396 & & & & \\
\hline \multirow{3}{*}{ F2: confidence } & Between groups & 454.438 & 3 & 151.479 & & & \multirow{3}{*}{$\begin{array}{c}9-11 \\
10-11\end{array}$} \\
\hline & Within groups & 8474.505 & 393 & 21.564 & 7.025 & $.000^{*}$ & \\
\hline & Total & 8928.942 & 396 & & & & \\
\hline \multirow{3}{*}{ F3: information acquisition } & Between groups & 179.111 & 3 & 59.704 & 1.915 & .127 & - \\
\hline & Within groups & 12250.663 & 393 & 31.172 & & & \\
\hline & Total & 12429.773 & 396 & & & & \\
\hline \multirow{2}{*}{ F4: performance } & Between groups & 82.348 & 3 & 27.449 & 1.473 & .221 & - \\
\hline & Within groups & 7324.725 & 393 & 18.638 & & & \\
\hline
\end{tabular}


When Tables 6 and 7 are examined together, the average scores on the motivation scale among the students learning geography differ according to grade level, but this difference is not statistically significant $(\mathrm{F}=2.309$; $\mathrm{p}>.05)$. There is no significant difference in the subfactors of interest $(\mathrm{F}=2.216 ; \mathrm{p}>.05)$, information acquisition $(\mathrm{F}=1.915 ; \mathrm{p}>.05)$ and performance $(\mathrm{F}=1.473 ; \mathrm{p}>.05)$, while there is a significant difference in the subfactor of confidence $(\mathrm{F}=7.025 ; \mathrm{p}<.05)$. The Bonferroni test determines the significance of this difference between classes. Accordingly, 11th grade students' self-confidence is significantly higher than that of ninth and 10th grade students.

Table 8 . The analysis results in respect of the motivation scale for learning geography

\begin{tabular}{|c|c|c|c|}
\hline Scale/subfactors & $\mathrm{N}$ & $\bar{X}$ & Ss \\
\hline \multicolumn{4}{|l|}{ Interest } \\
\hline 1. The subject of geography is interesting to me & 397 & 3.27 & 1.18 \\
\hline 2. Any kind of document related to geography is interesting to me & 397 & 2.79 & 1.04 \\
\hline 3. I would like to know about prominent geographers & 397 & 2.95 & 1.16 \\
\hline 4. I would like to take part in activities about geography & 397 & 2.90 & 1.18 \\
\hline 5. I prefer books on geography when I choose a book & 397 & 2.22 & 1.02 \\
\hline 6. Geography is interesting to me because it relates to current events & 397 & 3.10 & 1.18 \\
\hline \multicolumn{4}{|l|}{ Confidence } \\
\hline 7. I believe that I will get a high score in my geography lesson & 397 & 3.47 & 1.20 \\
\hline 8. I am confident when I talk about geography & 397 & 3.33 & 1.05 \\
\hline 9. I am sure I will understand whether the subject of geography is easy or not & 397 & 3.27 & 1.08 \\
\hline 10. I believe that I will be successful in my geography examination & 397 & 3.56 & 1.09 \\
\hline 11. I trust myself when I participate in my geography lesson & 397 & 3.54 & 1.08 \\
\hline \multicolumn{4}{|l|}{ Information acquisition } \\
\hline 12. I would like to learn about developments in geography & 397 & 3.31 & 1.11 \\
\hline 13. I would like my teacher to give a more detailed explanation during the geography lesson & 397 & 3.06 & 1.23 \\
\hline 14. I would like to investigate the causes and consequences of current geographical events & 397 & 3.09 & 1.14 \\
\hline 15. I would like to have access to many sources related to geography & 397 & 3.04 & 1.09 \\
\hline 16. I want to exchange information about my knowledge of geography with my friends & 397 & 3.00 & 1.12 \\
\hline 17. I want to receive homework in order to learn more about geography & 397 & 2.22 & 1.10 \\
\hline 18. I also want to learn about geography subjects that are not taught in school & 397 & 2.61 & 1.26 \\
\hline \multicolumn{4}{|l|}{ Performance } \\
\hline 19. I would like to get the highest grade in my geography examination & 397 & 4.08 & 1.20 \\
\hline 20. I want to be able to answer every question about geography & 397 & 4.02 & 1.18 \\
\hline 21. I want to be the best in all kinds of activities related to geography & 397 & 3.67 & 1.28 \\
\hline 22. I would like to answer every question about geography that no one knows the answer to & 397 & 3.96 & 1.25 \\
\hline
\end{tabular}

When Table 8 is examined, it can be seen that the following statements received the lowest score: 'I prefer books on geography when I choose books' and 'I want to receive homework in order to learn more about geography' $(\bar{X}=2.22)$. The following statements received the highest score: 'I would like to get the highest grade in my geography examination' ( $\bar{X}=4.08)$ and 'I want to be able to answer every question about geography' $(\bar{X}=4.02)$. The latter finding also indicates that these high school social science students are focused on performance so as to answer questions about geography and receive high grades in their examinations. However, it can also be assumption that this reflects a genuine interest in geography as a subject and learning more in geography lessons. When the results are examined in a general way, it can be seen low scores concern the subfactors of interest and information acquisition, while high scores concern self-confidence and performance.

\section{Conclusion, Discussion and Suggestions}

As a result of this research, which aims to determine the level of motivation level among high school social science students towards learning geography, it can be seen that the level of motivation is moderate. The analysis based on the scale and subscales reveals that the students present an average score in the categories of interest and information acquisition, which indicates indecisiveness, while the categories of self-confidence and performance can be regarded as being decisive. In the study conducted by Alim (2008), attitudes among 
secondary school students towards geography courses were at a moderate level, as they found geography lessons boring. I believe that students will be successful in geography lessons if attention is paid to the findings of Aydın's (2010a) study on the motivation of secondary students in geography lessons, particularly in relation to improving results as a result of greater self-confidence and performance. Meanwhile, the study conducted by Dikmenli and Çiftçi (2016) finds the level of motivation towards learning geography at the intermediate level when the lesson is compared to another lesson, as students do not give any particular importance to geography lessons. To this extent, it can be argued that students do not understand the importance of geography. If this is the case, geography lessons should not be about memorizing information in order to gain high marks. For this reason, it is necessary to help students to understand the importance of geography by geography this subject in an effective way.

When the results of the research are examined, it can be seen that there is a big difference in the motivation levels among high school social science students between genders: the average score of the motivation level in geography for female students is $\bar{X}=69.12$, while for male students it is $\bar{X}=72.76$. In other words, male students' level of motivation towards learning geography is higher than that of female students. The information presented here has similarities with the results of research studies on the attitudes of high school students, as observed during a geography lesson (Özgen \& Bindak, 2009; Zaman \& Coşkun, 2007). As is known, there is a positive effect on one's motivation and a positive attitude towards the lesson. As a result of the scale subfactors, it has been determined that male students have higher motivation levels in respect of interest and self-confidence, but there is no difference between genders in terms of information acquisition and performance.

Regarding the analysis of the motivation scores for learning geography, it has been stated that the scores of the students are different from the scores of the scale and subfactors. It can be concluded that these differences, which are based on scores, are statistically significant for those in the ninth, 10th and 11th grades in terms of self-confidence. In other words, the motivation level for learning geography is different according to the class level. This finding has been proven by the research conducted by Aydın (2010a), whose study showed a difference according to the class level. The findings of the study conducted by Aydin and Coşkun (2011) confirm that one's success and motivation differ according to the class level. The findings of another research study are similar to those of Ünlü's (2011) study, which indicated that the level of motivation based on geographical skills increased among high school students. In light of these results, it can be interpreted that there is a limited number of geography-related subjects in secondary schools, which in turn undermines the importance of geography courses.

As a result of the analysis of the scale, the following statements received the lowest average score: 'I prefer books on geography when I choose books' and 'I want to receive homework in order to learn more about geography'. On the other hand, these statements received the highest average score: 'I want to get the highest score in my geography examination' and 'I want to be able to answer every question about geography'.

Why is it important to geography learn? According to Kocalar and Demirkaya (2014), the perceptions of high school students "are similar to the finding that half of the students in social sciences do not like geography". It may be a contradiction that students are required to have high marks in their examination, solve questions in textbooks, obtain information and cultivate an interest in geography. However, it can be argued that the approach taken by students in this regard reflects the importance placed on examinations in the current system. Aydin (2010b) has stated that, for the majority of the students who, despite showing effort and individual progress in lectures, are ignored, evaluation by examination is a concern. This study has revealed that the level of motivation towards geography lessons may in fact have a negative influence on students. As such, teachers should organize activities, which include active participation and evaluation, in order to increase the interest of their students. Furthermore, in order to increase the motivation of the students in geography lessons, learning by practicing and experiencing should be used instead of transferring knowledge based on memorization. As a matter of fact, Aydın (2012) revealed that most of the high school social sciences students did not realize in their daily life that they learned in geography lessons.

According to the results obtained from this research, the level of motivation among high school social science students is moderate towards learning geography. To this extent, it is suggested that geography courses should be designed in order to increase the interest and motivation of students, for example, by basing lessons on the subject's relevance to everyday life and principles. The necessary equipment and materials should be used on geography courses, along with the creation of multidimensional laboratories and classes for social science students. In addition, geography curricula, teacher competences, and teaching methods and techniques should all be considered when seeking to identify the factors affecting the motivation of students in social sciences towards learning geography. 


\section{References}

Ainley, M. (2006). Connecting with learning: Motivation, affect and cognition in interest processes. Educational Psychology Review, 18(4), 391-405. https://doi.org/10.1007/s10648-006-9033-0

Akbaba, S. (2006). Eğitimde motivasyon [Motivation in education]. Atatürk Üniversitesi Kazım Karabekir Eğitim Fakültesi Dergisi [Journal Of Kâzım Karabekir Educatıon Faculty], (13), 343-361.

Alım, M. (2008). Lise öğrencilerinin coğrafya dersine yönelik tutumları [The Attitude of High School Students Towards Geography Course]. Doğu Coğrafya Dergisi [Eastern Geographical Review], 13(19), 25-32.

Aydın, F., \& Coşkun, M. (2011). Secondary school students' achievement motivation towards geography lessons. Archives of Applied Science Research, 3(2), 121-134.

Aydın, F. (2009). İşbirlikli öğrenme yönteminin 10.sinıf coğrafya dersinde başarlya, tutuma ve motivasyona etkileri [Effects of cooperative learning method on the achievement, attitude and motivation at 10th grade geography course] (Unpublished Doctoral Dissertation). Gazi University, Ankara.

Aydın, F. (2010a). Ortaöğretim öğrencilerinin coğrafya derslerindeki güdülenmelerinin incelenmesi [Examınation of secondary school students' motivations in geography lessons]. Turkish Studies, 5(4), 814-834.

Aydın, F. (2010b). Ortaöğretim öğrencilerinin coğrafya dersinde güdülenmelerine olumsuz etki eden faktörlere ilişkin görüşleri [Secondary school students' views about negative factors that influence motivations in geography lessons]. Ballkesir Üniversitesi Sosyal Bilimler Enstitüsü Dergisi [Ballkesir University The Journal of Social Sciences Institute], 13(24), 31-43.

Aydın, F. (2012). Sosyal bilimler lisesi öğrencilerinin coğrafya dersinin öğretimine yönelik görüşleri [Social sciences high school students opinions towards teaching of geography course]. Kastamonu Ë̆itim Dergisi [Kastamonu Education Journal], 20(3), 1035-1050.

Batdı, V., \& Semerci, Ç. (2016). İngilizce öğretiminde işbirlikli öğrenme destekli eğitsel eğlenceli etkinliklerin öğrencilerin motivasyonlarına etkisi [The effect of educational entertaining activities supported with co-operative learning in teaching english]. Kastamonu Üniversitesi Kastamonu Ë̆itim Dergisi [Kastamonu Education Journal], 24(2), 493-510.

Demirel, Ö. (2009). Öğretme Sanatı (15. Baskı). Ankara: Pegem Akademi Yayıncılık.

Dikmenli, Y., \& Çif̧̧i, T. (2016). Lise öğrencilerinin coğrafya dersine yönelik görüşleri [High school students' views about geography course]. Turkish Studies, 11(3), 911-928. https://doi.org/10.7827/TurkishStudies.9108

Dörnyei, Z. (2000). Motivation in action: towards a process-oriented conceptualisation of student motivation. British Journal of Educational Psychology, 70(4), 519-538. https://doi.org/10.1348/000709900158281

Ergün, M. (2014). Sinıfta Motivasyon. In E.Karip (Ed.), Sinıf Yönetimi (pp. 133-148). Içinde. Ankara: Pegem Akademi Yayıncllık.

Frymier, A. B. (1993). The impact of teacher immediacy on students' motivation: Is it the same for all students? Communication Quarterly, 41(4), 454-464. https://doi.org/10.1080/01463379309369905

Girmus, R. L. (2011). How to motivate your students. Austin, TX: National Institute for Staff and Organizational Development Conference

Göğüş, A. \& Yetke, Ş. (2014). Öğretme yöntemlerinin çeşitlendirilmesi ile öğrenci motivasyonunun artırılması: ingilizce dersi öğretmen liderliği örneği [Increasing student motivation through diversification of instructional methods: the case of teacher leadership in english course]. Uludağ Üniversitesi Ĕgitim Fakültesi Dergisi [Journal of Uludag University Faculty of Education], 27(2), 284-305.

Gülşen, C. (2015). Sınıfta motivasyon sürecinin etkili yönetimi. In C. Gülşen (Ed.), Kuram ve uygulamada sinıf yönetimi (pp. 166-192). Içinde. Ankara: Anı Yayıncılık.

$\mathrm{Hu}, \mathrm{Y}$. (2008). Motivation, usability and their interrelationships in a self-paced online learning environment. (Doctoral dissertation, Virginia Polytechnic Institute and State University, Virginia).

Karasar, N. (2011). Bilimsel araştırma yöntemi (22.Baskı). Ankara: Nobel Akademi Yayıncılık.

Kaya, M. F. (2013). Coğrafya öğrenmeye yönelik motivasyon ölçeği geliştirme çalışması [Study for ımproving motivation scale of secondary school students in learning geography]. Doğu Coğrafya Dergisi [Eastern Geographical Review], 18(30), 155-174. 
Kocalar, A.O. \& Demirkaya, H. (2014). Coğrafya öğrenmek niçin önemlidir? lise öğrencilerinin algıları [Why is geography important to learn? perception of high school students]. Doğu Coğrafya Dergisi [Eastern Geographical Review], 19(32), 123-144. https://doi.org/10.17295/dcd.49497

Kubanyiova, M. (2006). Developing a motivational teaching practice in EFL teachers in slovakia: Challenges of promoting teacher change in EFL contexts. TESL-EJ, 10(2), 1-17.

Loima, J., \& Vibulphol, J. (2016). Learning and motivation in Thailand: A comparative regional study on basic education ninth graders. International Education Studies, 9(1), 31-43. https://doi.org/10.5539/ies.v9n1p31

Mensah, E. (2015). Middle level students' goal orientations and motivation. Journal of Education and Training Studies, 3(2), 20-33. https://doi.org/10.11114/jets.v3i2.617

Moos, D. C., \& Honkomp, B. (2011). Adventure learning: Motivating students in a Minnesota middle school. Journal of Research on Technology in Education, 43(3), 231-252. https://doi.org/10.1080/15391523.2011.10782571

Noland, A., \& Richards, K. (2014). The Relationship among Transformational Teaching and Student Motivation and Learning. Journal of Effective Teaching, 14(3), 5-20.

Özbay, Y. (2003). Gelişim ve öğrenme psikolojisi (4.Bask1). Trabzon: Akademi Kitapevi.

Özgen, N., \& Bindak, R. (2009). Lise öğrencilerinin coğrafya dersine yönelik tutumlarının çeşitli değişkenlere göre incelenmesi Siirt örneği [The examination in terms of certain variables of attitude towards geography of high school students: the sample of Siirt]. Gazi Üniversitesi Gazi Eğitim Fakültesi Dergisi [Gazi University Journal of Gazi Educational Faculty], 29(2), 421-440.

Sezer, A. (2006). IX. sınıf öğrencilerinin öğrenme stilleri ile coğrafya dersi başarı puanları ve coğrafya dersine yönelik tutumları arasındaki ilişkilerin incelenmesi [The relationships between geograpby courses of point of achievement and attitudes of towards geography courses and learning styles of 1x. grade students]. Atatürk Üniversitesi Kazım Karabekir Eğitim Fakültesi Dergisi [Journal Of Kâzım Karabekir Educatıon Faculty], (13), 1-10.

Singh, S. S. B., Kleeman, G., \& Van Bergen, P. (2013). A conceptual framework for assessing the impacts of GIS on the motivation and achievement in geography among underachieving students of smart school in Sabah, Malaysia. US-China Education Review A, 3(2), 100-107.

Ünlü, M. (2011). Coğrafya derslerinde coğrafi becerilerin gerçekleşme düzeyi [The level of realizing geographical skills in geography lessons]. Kuram ve Uygulamada Eğitim Bilimleri [Educational Sciences: Theory \& Practice], 11(4), 2155-2172.

Yüksel, G. (2011). Öğrenme için motivasyon. In M. Ç. Özdemir (Ed.), Sinıf yönetimi (pp. 17-43). Içinde. Ankara: Pegem Akademi Yayıncilık.

Zaman, S., \& Coşkun, O. (2007). Orta öğretim öğrencilerinin coğrafya derslerine karşı tutumları üzerine bir araştırma: Erzurum örneği [A research on the attitudes of high school students towards geography courses: The erzurum sample]. Doğu Coğrafya Dergisi[Eastern Geographical Review], 12(17), 17-31.

\section{Copyrights}

Copyright for this article is retained by the author(s), with first publication rights granted to the journal.

This is an open-access article distributed under the terms and conditions of the Creative Commons Attribution license (http://creativecommons.org/licenses/by/4.0/). 